Article

\title{
Exclusion of Estrogenic and Androgenic Steroid Hormones from Municipal Membrane Bioreactor Wastewater Using UF/NF/RO Membranes for Water Reuse Application
}

\author{
Mujahid Aziz *(i) and Tunde Ojumu(i) \\ Faculty of Engineering and the Built Environment, Department of Chemical Engineering, \\ Cape Peninsula University of Technology, Bellville, Cape Town 7435, South Africa; OjumuT@cput.ac.za \\ * Correspondence: azizm@cput.ac.za; Tel.: +27-(0)21-460-4292
}

Received: 22 December 2019; Accepted: 20 February 2020; Published: 27 February 2020

\begin{abstract}
In the context of water scarcity, domestic secondary effluent reuse may be an option as a reliable source for alleviating acute water shortage. The increasing risks linked with the presence of natural steroid hormones and many emerging anthropogenic micropollutants (MPs) passing through municipal wastewater treatment works (MWWTWs) are of concern for their endocrine-disrupting activities. In this study, domestic wastewater treated by a full-scale membrane bioreactor (MBR) at an MWWTW in the Western Cape Province, South Africa, was used directly as the influent to a reverse osmosis (RO) pilot plant for the removal of selected natural steroid hormones $17 \beta$-estradiol $\left(E_{2}\right)$ and testosterone $(\mathrm{T})$ as a potential indirect water recycling application. Estrogenicity and androgenicity were assessed using the enzyme-linked immunosorbent assays (ELISA) and the recombinant yeast estrogen receptor binding assays (YES). The influent $\mathrm{pH}$ and flux did not influence the rejection of $\mathrm{E}_{2}$ and $\mathrm{T}$, which was most likely due to adsorption, size exclusion, and diffusion simultaneously. $\mathrm{RO}$ and nanofiltration (NF) exhibited excellent removal rates ( $>95 \%)$ for $\mathrm{E}_{2}$ and $\mathrm{T}$. All the $\mathrm{E}_{2}$ effluent samples with MBR/ultrafiltration (UF), MBR/NF, and MBR/RO were lower than the US EPA and WHO trigger value of $0.7 \mathrm{ng} / \mathrm{L}$, as well as the predicted no-effect concentration (PNEC) values for fish (1 $\mathrm{ng} \mathrm{E} / \mathrm{L}$ ).
\end{abstract}

Keywords: membrane bioreactor (MBR); ultrafiltration (UF); nanofiltration (NF); reverse osmosis (RO); androgen; estrogen; steroid hormones; level of detection (LOD); micro pollutions (MPs); predicted no-effect concentration (PNEC)

\section{Introduction}

The growing fear of a shortage of water resources is becoming an important topic as a severe paucity of water has been seen all over the globe. There is an increasing concern about the potentially harmful effects of some substances present in water bodies. These emerging micropollutants (MPs) have been shown to be present in both industrial and domestic wastewater in unnoticeable quantities, with concentrations ranging from micro- and nanograms per litre scales [1]. Several natural and human-made compounds have been shown to modulate endocrine activity in vertebrates. Compounds acting in this way are collectively referred to as endocrine-disrupting chemicals (EDCs). These chemicals enter the sewer system through disposal or excretion and are not completely removed during wastewater treatment. Numerous studies have detected EDCs, such as natural steroidal hormones [2] and pharmaceuticals and personal care products (PPCPs) in environmental samples. Studies have shown antagonistic effects on aquatic wildlife [3] that have been linked to the presence of EDCs and PPCPs. These natural hormones are responsible for maintenance, reproduction, development, and behaviour of organisms [4]. Among the sources of these substances are natural steroid hormones, 
industrial chemicals, pharmaceuticals, and many others [5]. Many researchers have investigated the effect of these substances in water bodies, observing harmful effects on humans and animals, such as endocrine system anomalies, cancer, reduction of sperm quantity, and endometriosis [6]. Authors have confirmed decreased testosterone levels heightened anxiety [4] The natural steroid estrogens, estrone $\left(E_{1}\right), 17 \beta$-estradiol $\left(E_{2}\right)$, and estriol $\left(E_{3}\right)$, and the synthetic $17 \alpha$-ethinylestradiol $\left(E_{2}\right)$, are the most widely investigated because of their high estrogenicity at low concentrations and their presence in several matrixes, such as drinking, ground, and surface water, as well as effluents from municipal wastewater treatment works (MWWTW) [7]. $E_{1}, E_{2}$, and $E_{3}$ are primarily female hormones. The most potent estrogen, $17 \beta$-estradiol $\left(\mathrm{E}_{2}\right)$, and its precursor, $\mathrm{T}$, play critical roles in mammalian reproductive processes. Evidence indicates that these steroids are present in a bioactive form in the excretions of many male mammals [8]. The natural androgen, $\mathrm{T}$, and the natural estrogen, $\mathrm{E}_{2}$, will end up in the environment through sewage discharge and animal waste disposal [9].

The treated sewage effluent and natural surface water mixture found in the City of Cape Town $(\mathrm{CoCT})$ rivers are used directly for irrigation in the agricultural areas. The Western Cape Province, South Africa, has a high rainfall in winter with very low or no rain in summer. During the summer months, most of the water in these rivers is treated sewage effluent [10]. Thus, estrogens and androgens are not completely removed by MWWTWs, justifying this research to find more efficient processes to remove these intractable pollutants. Given that conventional treatment processes are less efficient, the scientific community set out in search of novel processes and operating conditions, which could increase the treatment efficiency of wastewater [11]. Nanofiltration (NF) and reverse osmosis (RO) membrane filtration processes have also been used to produce high-quality water from non-traditional sources such as brackish, seawater, or secondary treated wastewater [12]. Research has demonstrated the excellent capacity of NF/RO to remove a large range of MPs in pilot and full-scale applications [13].

Municipal wastewaters are mostly treated by conventional activated sludge (CAS) or membrane bioreactor (MBR) processes. The MBR process is simply an integrated treatment system of microfiltration (MF) or ultrafiltration (UF) membranes with a biological reactor where secondary effluents often include high concentrations of dissolved matter, pesticides, pathogen, heavy metals, and micropollutants [14], thus making tertiary treatment a necessity for potential water reuse. Although tertiary processes play an essential role and can be applied after the secondary process at MWWTPs, there is still a lack of information about these processes and their EDC removal capacity from environmental matrixes at trace concentration [15]. Over the last decades, the use of membrane technology has grown considerably in wastewater treatment. It has proven to be an effective method for the removal of a wide variety of contaminants from wastewater. Some studies concluded that an integrated system of MBR-NF/RO could be considered as a good alternative for the recovery and reuse of treated wastewater for irrigation [16-18].

Total estrogenicity of a sample is commonly measured to avoid exhaustive chemical analysis in chemically complex samples, including wastewaters [19]. Enzyme-linked immunosorbent assay (ELISA) and yeast estrogen screen (YES) bio screening assays are strong, rapid, simple, and cost-effective methods for quantitative analysis of estrogenic hormones, such as $E_{2}$ and $T$ [10]. These in vitro bioassays play a crucial role for the ecotoxicological assessment of water and wastewater quality because they determine the joint toxicity caused by complex samples, often regarding a specific mode of action [20].

In 2018, the City of Cape Town (CoCT) suffered a third consecutive year of severe drought due to unpredictable weather patterns resulting in a significant shortage of water in the Western Cape Province, South Africa. Water reuse may be an option to alleviate acute water shortages if appropriate treatment technologies can be developed. This study aimed to demonstrate the complementarities of combining a RO pilot plant with a full-scale MBR at a MWWTW while investigating the concentration and removal efficiencies of an estrogen ( $17 \beta$-estradiol) and an androgen (testosterone) steroid hormone, detected in the influent and effluents with UF, NF, and RO membranes for potential indirect potable water reuse. 


\section{Materials and Methods}

\subsection{Full-Scale MBR}

The WWTW with a full-scale MBR plant is located in the Western Cape and receives its wastewater from the largest informal settlement in the province. Raw sewage from the WWTW served as the feed, after filtration, for the MBR. The MBR output was filtered in a membrane tank by a commercially available, plate and frame type, hollow fibre, submerged UF membrane. The MBR system incorporates ZeeWeed 500 ultrafiltration membranes (GE Zenon), producing 18 megalitres of effluent per day.

\subsection{RO Pilot Plant}

The contaminant removal efficiency was evaluated at a WWTW designated for possible agricultural, recreational, and potable reuse of wastewater effluents. This treatment plant consists of a full-scale membrane bioreactor (MBR) plant receiving wastewater from a densely populated residential area followed by UF/NF/RO pilot plant. The pilot plant consisted of three different thin film composite (TFC) polyamide (PA) membrane modules, in parallel, which was subjected to various experimental running conditions (Table 1). Secondary MBR effluent was used (Table 2) to feed into the pilot plant (Figure 1). Batch, $8 \mathrm{~h}$, once through mode experimental runs were conducted on the pilot plant with individual membranes at any given time. Permeate $\left(C_{P}\right)$ and feed $\left(C_{F}\right)$ conductivities were used to evaluate the salt rejection $(R)$ of the membrane as shown in Equation (1) [21]. Different operating conditions of flux and percentage recovery were used during the experimental runs. Table 1 shows a summary of the experimental conditions. The permeate flux $(J)$ was calculated using the volume of permeate $(V)$ collected through the active surface area of membrane $(A)$ for a given period of time $(\Delta t)$, as shown in Equation (2) [12].

$$
\begin{gathered}
R=\left(1-\frac{C_{p}}{C_{f}}\right) \times 100 \\
J=\frac{V}{A \Delta T}
\end{gathered}
$$

Table 1. Pilot plant operating conditions.

\begin{tabular}{cccc}
\hline Parameters & \multicolumn{3}{c}{ Operating Conditions } \\
\hline Membrane module & XLE & NF270 & UA60 \\
Recovery $(\%)$ & $50 ; 75$ & 75 & 75 \\
Flux $\left(\mathrm{L} / \mathrm{m}^{2} \mathrm{hr}^{1}\right)$ & $25 ; 30$ & 30 & 30 \\
$\mathrm{pH}$ & uncontrolled; 6.5 & uncontrolled & uncontrolled \\
\hline
\end{tabular}

Table 2. The physicochemical characteristics of the membrane bioreactor (MBR) effluent.

\begin{tabular}{cccc}
\hline Parameter & Units & Average MBR Effluent & Limit * \\
\hline Electron conductivity $(\mathrm{EC})$ & $\mathrm{mS} / \mathrm{m}$ & 56 & $75^{*}$ \\
$\mathrm{pH}$ & & 6.9 & $5.5-9.5^{*}$ \\
Chemical oxygen demand (COD) & $\mathrm{mg} / \mathrm{L}$ & $<20$ & $75^{*}$ \\
Ammonium $\left(\mathrm{NH}_{4}{ }^{2-}\right)$ & $\mathrm{mg} / \mathrm{L}$ & $<0.4$ & $1.0^{*}$ \\
Phosphate $\left(\mathrm{PO}_{4}\right)$ & $\mathrm{mg} / \mathrm{L}$ & 2.6 & $10^{*}$ \\
Nitrate $\left(\mathrm{NO}^{3}\right)$ & $\mathrm{mg} / \mathrm{L}$ & 13 & $15^{*}$ \\
Chloride $\left(\mathrm{Cl}^{-}\right)$ & $\mathrm{mg} / \mathrm{L}$ & 73 & $100^{*}$ \\
$17 \beta$-Estradiol $\left(\mathrm{E}_{2}\right)$ & $\mathrm{ng} / \mathrm{L}$ & $<5$ & - \\
Testosterone $(\mathrm{T})$ & $\mathrm{ng} / \mathrm{L}$ & 120 & - \\
\hline
\end{tabular}

* Department of Water and Forestry (DWAF) 2010 guideline [22]. 


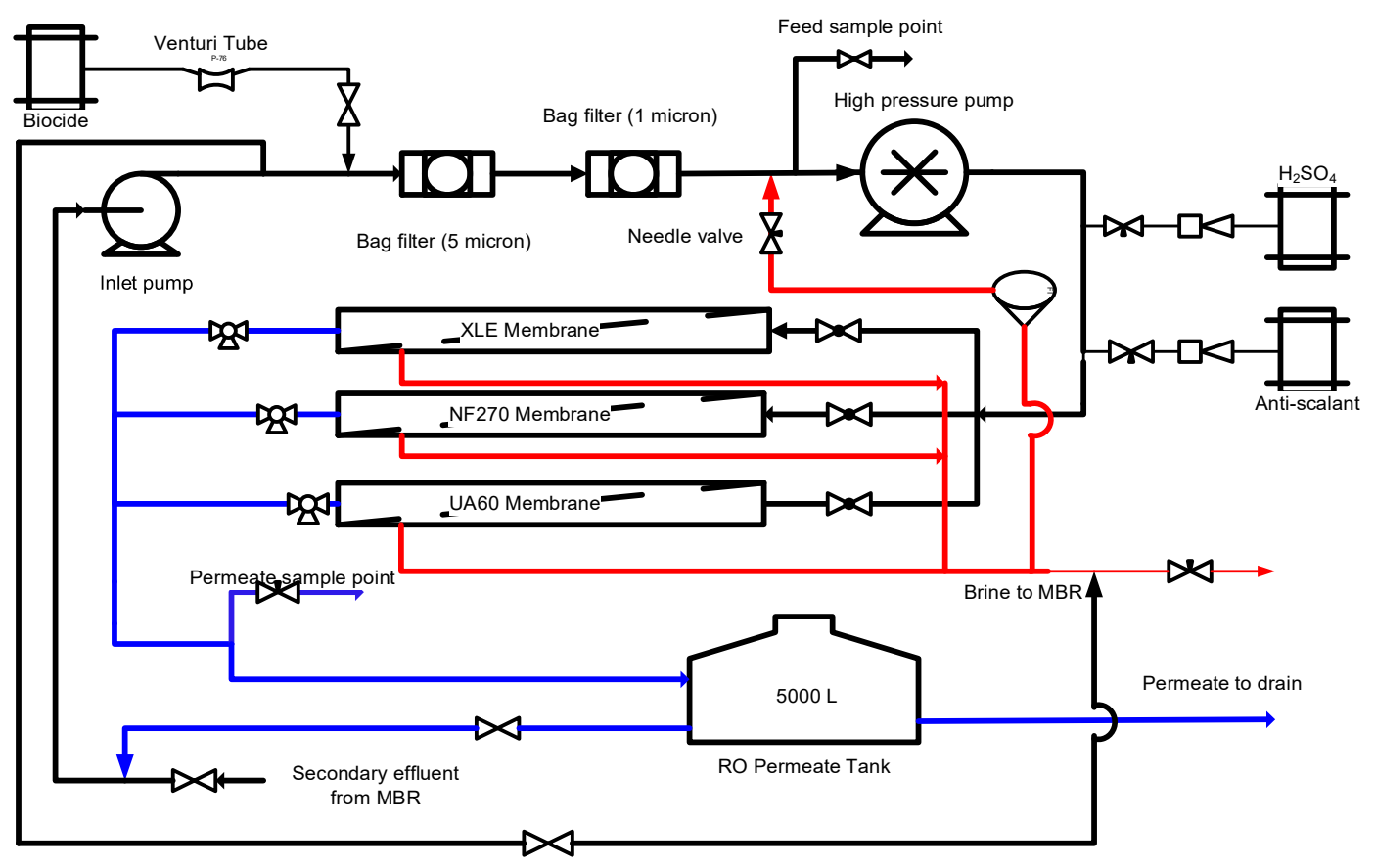

Figure 1. Process flow diagram of the ultrafiltration (UF)/nanofiltration (NF)/reverse osmosis (RO) pilot plant.

\subsection{UF/NF/RO Membranes}

High-pressure membranes examined in this project included the NF270 (Dow Chemical Co., Filmtec NF270-4040, Midland, MI, USA) polyamide TFC loose nanofiltration (NF) membranes, UA60 (TriSep, 4040-UA60-TSA, Goleta, CA, USA) piperazine-based TFC loose ultrafiltration (UF) membranes, and the XLE (Dow Chemical Co., Filmtec XLE-4040, Midland, MI, USA) polyamide TFC low-pressure reverse osmosis (RO) membrane. RO and NF membranes are considered thin-film composite comprising three layers: $0.2 \mu \mathrm{m}$ polyamide, $40 \mathrm{~mm}$ polysulfone, and $120 \mathrm{~mm}$ polyester support web. The characteristics of these membranes are presented in Table 3.

Table 3. Properties of three membrane modules.

\begin{tabular}{|c|c|c|c|c|c|c|c|c|}
\hline $\begin{array}{l}\text { Membrane } \\
\text { Component }\end{array}$ & Texture & Type & $\begin{array}{c}\text { Rejection } \\
\%\end{array}$ & $\begin{array}{c}\text { Effective } \\
\text { Area }\left(\mathrm{m}^{2}\right)\end{array}$ & $\begin{array}{l}\text { MWCO } \\
\text { (Da) }\end{array}$ & $\begin{array}{c}\text { Maximum } \\
\text { Pressure } \\
\text { (bar) }\end{array}$ & $\begin{array}{c}\text { Maximum } \\
\text { Temperature } \\
\left({ }^{\circ} \mathrm{C}\right)\end{array}$ & $\begin{array}{c}\text { Maximum } \\
\text { Permeate } \\
\text { Flowrate } \\
\left(\mathrm{m}^{3} / \mathrm{hr}\right)\end{array}$ \\
\hline NF & $\begin{array}{c}\text { TFC } \\
\text { Polyamide }\end{array}$ & $\begin{array}{c}\text { Filmtec } \\
\text { NF270-4040 }\end{array}$ & $\begin{array}{c}>97 \% \\
\mathrm{MgSO} 4\end{array}$ & 7.6 & 400 & 4.8 & 45 & 9.5 \\
\hline
\end{tabular}

\subsection{Estrogenic and Androgenic Steroid Hormones}

Target compounds selected for this study included natural steroidal hormones; an endogenous estrogen, $17 \beta$-estradiol $\left(\mathrm{E}_{2}\right)$; and an endogenous androgen, testosterone $(\mathrm{E})$. The physicochemical properties are presented in Table 4 [23], where the chemical structure shows that both $E_{2}$ and $T$ had two oxygen-containing functional groups, which took the form of primary or secondary alcohol or a ketone [24]. $\mathrm{E}_{2}$ and $\mathrm{T}$ had very low solubility in water. Their $\mathrm{K}_{\mathrm{ow}}$ values suggest their hydrophobic nature and moderate-to-high binding to organic colloids and macromolecules in water. 
Table 4. Physiochemical properties of a selected estrogen and androgen compound.

\begin{tabular}{cccccccc}
\hline Analytes & $\begin{array}{c}\text { MW } \\
(\mathrm{g} / \mathrm{mol})\end{array}$ & Formula & $\begin{array}{c}\text { CAS } \\
\text { Number }\end{array}$ & $\begin{array}{c}\text { Solubility } \\
(\mathbf{m g} / \mathbf{L})\end{array}$ & $\begin{array}{c}\text { Dissociation } \\
\text { Constant } \\
\mathbf{p K}\end{array}$ & Classification & $\begin{array}{c}\text { Partition. } \\
\text { Coefficient } \\
\left(\mathbf{l o g} \mathbf{K}_{\mathbf{o w}}\right)\end{array}$ \\
\hline $\begin{array}{c}17 \beta \text {-Estradiol } \\
\left(\mathrm{E}_{2}\right)\end{array}$ & 272.38 & $\mathrm{C}_{18} \mathrm{H}_{24} \mathrm{O}_{2}$ & $50-28-2$ & 13 & 10.4 & $\begin{array}{c}\text { Chemical } \\
\text { Structure } \\
\text { hormone } \\
\text { (estrogen) }\end{array}$ \\
\hline $\begin{array}{c}\text { Testosterone } \\
(\mathrm{T})\end{array}$ & 288.42 & $\mathrm{C}_{19} \mathrm{H}_{28} \mathrm{O}_{2}$ & $58-22-0$ & 23.4 & 17.4 & $\begin{array}{c}\text { natural } \\
\text { hormone } \\
\text { (androgen) }\end{array}$ \\
\hline
\end{tabular}

Physiochemical information was obtained from $[25,26]$.

\subsection{Sample Collection and Solid Phase Extraction (SPE)}

Sampling was carried out during May, June, and July as well as October, November, and December. The sampling points were (1) municipal wastewater raw-sewer (influent), (2) MBR influent, (3) MBR effluent, and (4) permeate of UF/NF/RO element. Grab samples were taken once weekly of both influent and effluent. To avoid frequent fluctuations in concentrations, each sample taken from the pilot plant was an $8 \mathrm{~h}$ composite sample taken for the duration of each experimental run.

All water samples were collected in amber glass bottles (2.5 L), covered with tin foil, placed on ice, kept in a cool box, and transported to the laboratory for testing. There was no contamination or contact with the plastic lid of the bottles. Once they reached the laboratory, the effluent samples were filtered through $1.0 \mu \mathrm{m}$ pore size glass fibre filter paper (Whatman $\mathrm{GF} / \mathrm{B}$ ), then the filtrates were stored in a refrigerator at $4{ }^{\circ} \mathrm{C}$, and solid-phase extraction (SPE) was performed within $48 \mathrm{~h}$.

\subsection{Enzyme-Linked Immunosorbent Assays (ELISAs)}

$17 \beta$-Estradiol $\left(\mathrm{E}_{2}\right)$ and testosterone $(\mathrm{T})$ concentrations were determined using enzyme-linked immunosorbent assay (ELISA) kits. Inter- and intra-assay variation for steroid hormone ELISAs are negligible, as shown by [10] who determined inter-assay variation at $5.6 \%(n=3)$ and intra-assay variation between $0.6 \%$ and $2.5 \%(n=3)$. Thus, the accuracy of the ELISAs reduces the need for expensive and time-consuming replication and provides for a rapid screen of several samples. All reagents required for the assays were supplied with the kits. $E_{2}$ and $T$ levels were determined in the C18 SPE extracts of water collected using commercially available ELISA kits ( $E_{2}$ and $T$, DRG International Inc., USA); according to the manufacturers' instructions. Assay ranges of the kits are estradiol 9.7-2000 ng/L and testosterone 83-16,000 $\mathrm{ng} / \mathrm{L}$. The extracted samples in ethanol $(1000 \times$ concentrated) were diluted $\left(\mathrm{E}_{2}, 1 / 10 ; \mathrm{T}, 2 / 10\right)$ in a $0.1 \% \mathrm{w} / \mathrm{v}$ human serum albumin and $0.9 \% \mathrm{NaCl}$ solution and were assayed [10]. The diluted samples were then assayed using the kit, and the data obtained were plotted on the same graph as the standard curve to determine if the curves were parallel. The kits were assayed for intra-assay reproducibility by assaying replicates of the same sample on a single assay plate. The OD was determined at $450 \mathrm{~nm}$ using a plate reader. A standard curve was drawn using the reading obtained for the standards; the concentrations of the samples were read off this curve. Faul et al. (2014) [27] found that the effective lower level of quantification (LOQ) for each were reduced to $0.97 \mathrm{ng} / \mathrm{L}$ (E2) and $4.15 \mathrm{ng} / \mathrm{L}$ (T), respectively. Truter et al. (2015) [28] had the detection limits for $\mathrm{E}_{2}$ at $0.37 \mathrm{ng} / \mathrm{L}$, after a solvent blank correction.

\subsection{In Vitro Recombinant Yeast Estrogen Screen (YES)}

The recombinant yeast-based screen followed the protocol described by Sohoni and Sumpter (1998). Saccharomyces cerevisiae transfected with the human estrogen receptor (hER) gene and a plasmid containing an estrogen response element-linked lac-Z gene was used. Successful binding of ligands in the water samples (steroids) to the receptors in the yeast cells initiate the expression of the lac- $Z$ reporter gene that encodes for the enzyme $\beta$-galactosidase in the assay. The $\beta$-galactosidase then metabolises chlorophenol red galactopyranoside (CPRG), which results in a colour change of the assay medium, 
indicating a dose-dependent activation of the ligands to bind to the estrogen receptor. The assay medium was prepared as described by [29]. The yeast was incubated in assay medium containing no $\mathrm{CPRG}$ for $48 \mathrm{~h}$ under $26^{\circ} \mathrm{C}$ on an orbital shaker. The concentrated wastewater extracts $(500 \times)$ were serially diluted and $10 \mu \mathrm{L}$ was spiked into the 96-well sterile flat-bottomed plates with low evaporation lids (Costar, 3370, Sigma). The previously incubated yeast culture was then included into new assay medium containing CPRG at a concentration of approximately $8 \times 105$ cells $/ \mathrm{mL}$. The seeded assay medium was then added at $200 \mu \mathrm{L} /$ well into the assay plate to provide a final concentration of the water extracts ranging from $50 \times$ to $1.56 \times$. A concentration of $1 \times$ was depicted as an un-concentrated water sample. For the raw wastewater samples, serial dilutions of the samples were made with $\mathrm{MeOH}$ to obtain a concentration range of each sample ranging from $12.5 \times$ to $0.39 \times$ in the assay due to cytotoxicity observed in the $50 \times$ and $25 \times$ concentrated sample. For the effluent (permeate) water samples, serial dilutions of the samples were made with $\mathrm{MeOH}$ to obtain a concentration range of each sample ranging from $50 \times$ to $6.25 \times$ due to the lower observed estrogenicity in these samples compared to raw wastewater samples. All samples were analysed in triplicate in the same assay plate, and each assay was repeated twice. A standard curve for the steroid hormone $17 \beta$-estradiol ( $\mathrm{E}_{2}$; CAS 50-28-2; Sigma) was included for each assay plate in 12 serial dilutions, ranging from 1.0 to $2700.0 \mathrm{ng} / \mathrm{L}$. Blank wells were also included in each assay plate containing only assay medium without any hormone spike or water sample extracts. The assay plates were then allowed to incubate on a shaker for $72 \mathrm{~h}$ at $30^{\circ} \mathrm{C}$ under dark conditions [30].

\subsection{Statistical Analysis}

All statistical analyses were performed using GraphPad Prism (v. 5.00) and Microsoft Excel 2010. The variation between individual samples was assessed using an unpaired $t$-test. For the determination of significant variation between sampling and membranes, a one-way analysis of variance (ANOVA) was performed. Significant variance was achieved with $p<0.05$.

\section{Discussion}

\subsection{ELISA Analysis of $17 \beta$-Estradiol $\left(E_{2}\right)$ and Testosterone $(T)$}

Estradiol was detected in all influent samples analysed (Figure 2A). The highest $\mathrm{E}_{2}$ concentration was detected in the raw influent sample $(80.22 \mathrm{ng} / \mathrm{L})$, followed by the average MBR influent $(7.61 \mathrm{ng} / \mathrm{L})$, and effluent (4.84 ng/L). The MBR effluents (RO influent) for May, June, and July were 5.35, 3.39, and $6.71 \mathrm{ng} / \mathrm{L}$, respectively. The highest concentrations of estradiol were found in the raw influent (Figure 2A), which was confirmed by Faul et al. (2013) [31] who measured $E_{2}$ at the sewage inlet plant in Windhoek, Namibia at 78ng/L. A 91\% removal of $\mathrm{E}_{2}$ was recorded in the anaerobic (anoxic) tank, where the raw influent was reduced from almost 80.22 to $7.61 \mathrm{ng} / \mathrm{L}$. The lowest percentage removal (36\%) (Figure 2C) was measured by the MBR aerobic (oxic) tank, where the MBR influent was reduced from 7.61 to $4.85 \mathrm{ng} / \mathrm{L}$ only. UF, NF, and RO had an expected percentage removal of $54 \%, 84 \%$, and $97 \%$. The change in MBR influent and effluent can be seen in Figure 2C, where the error was notable. This is an indicator confirming the fluctuation of the inlet streams. $\mathrm{E}_{2}$ was completely removed to below level of detection (LOD) for all XLE treatment processes with its removal efficiency of $>93 \%$. This agrees to previous results reported by Lee et al. (2008) [32] for secondary processes. The UF, $\mathrm{NF}$, and RO effluents in sequence with MBR process were conserved to give very good efficiencies for the removal of $E_{2}$ and T. Figure $2 C$ shows that the $E_{2}$ concentration for the effluents of MBR, UF, $\mathrm{NF}$, and $\mathrm{RO}$ in sequence with MBR process had very low $\mathrm{E}_{2}$ concentrations of 4.85, 2.22, 0.66, and $0.16 \mathrm{ng} / \mathrm{L}$. NF and RO effluents had significantly reduced $\mathrm{E}_{2}$ concentrations compared with the influent at $7.61 \mathrm{ng} / \mathrm{L}$ ( $p=0.007$ at for UF, $p=0.00027$ for NF, $p=0.00016$ for RO; $\alpha=0.05$ ). This is consistent with a similar study of MBR/NF and MBR/RO membrane effluent rejection [33]. MBR is considered a relatively better treatment process for the removals of steroids compared to conventional activated sludge processes alone [34]. Likewise, micropollutants (MPs), such as $\mathrm{E}_{2}$ and $\mathrm{T}$, can be removed by 
size exclusion and adsorption mechanisms using ultrafiltration (UF), nanofiltration (NF), and reverse osmosis (RO). The study by Lee et al. (2008) [32] showed that steroid hormones such as $E_{2}$ can be removed by $\mathrm{MBR} / \mathrm{RO}$ processes by $99 \%$.
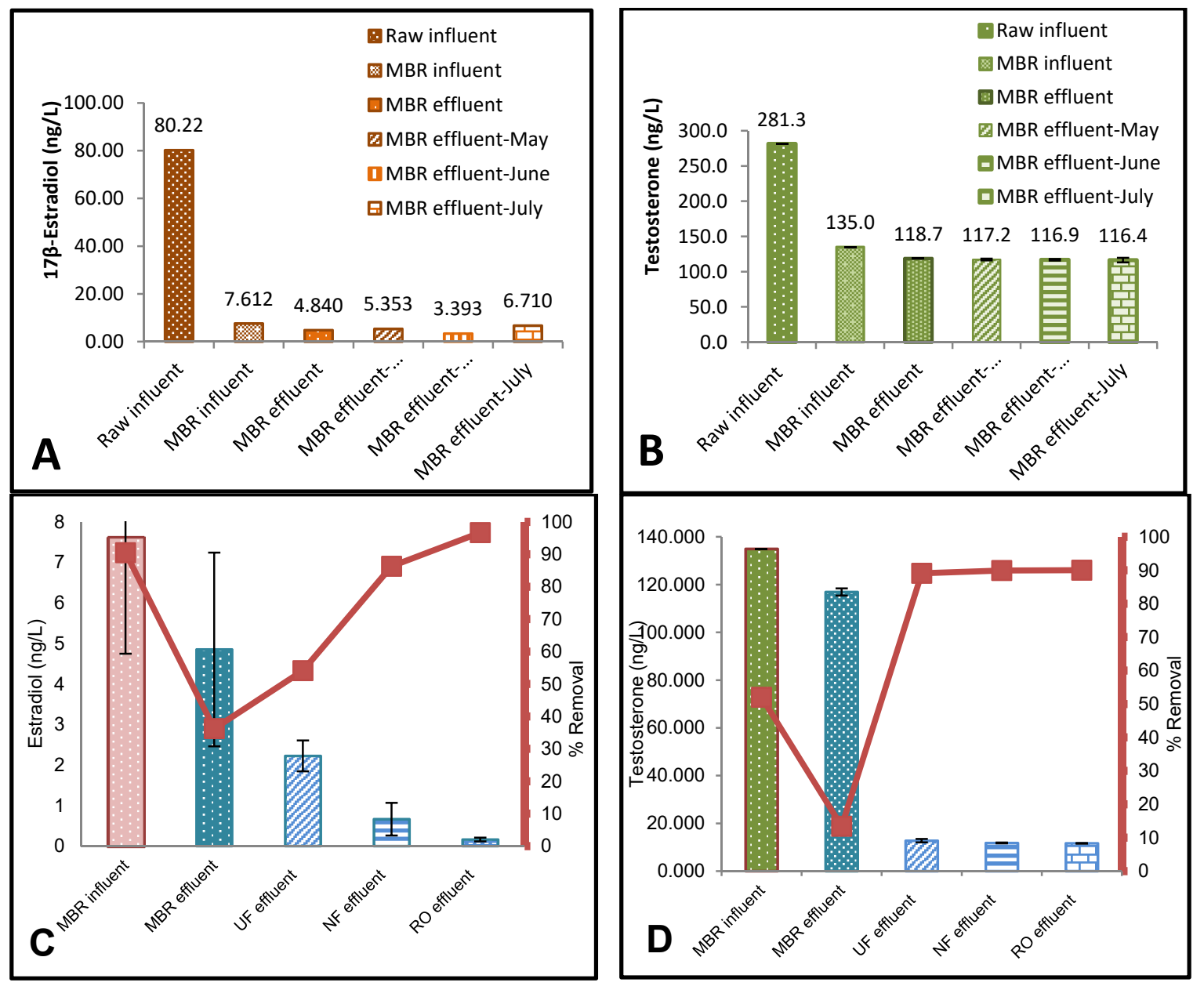

Figure 2. $17 \beta$-Estradiol $\left(\mathrm{E}_{2}\right)$ and testosterone $(\mathrm{T})$ measured activity in collected samples from raw MWWTW and MBR influents as well as MBR effluents at six stages over three months. (A) shows the $\mathrm{E}_{2}$ ELISA analysis during May, June, and July. (B) shows the T ELISA analysis during the months of May, June, and July. (C) The mean of $17 \beta$-estradiol $\left(E_{2}\right)$ levels $(\mathrm{ng} / \mathrm{L})$ measured in water collected from influents at five stages within the MWWTW including MBR and RO feed and permeate during winter (May, June, and July) Error bars denote SD; $n=2$. Error bars show maximum levels detected. (D) The mean of testosterone (T) levels (ng/L) measured in water collected from influents at five stages within the MWWTW including MBR and RO feed and permeate during winter (May, June, and July). Error bars denote $\mathrm{SD} ; n=2$. Error bars show maximum levels detected.

Testosterone (T) was detected in all feed samples analysed (Figure 2B). The highest $\mathrm{T}$ concentration was detected in the raw influent sample (281.3 ng/L), followed by the average MBR influent (135.0 ng/L) and effluent (118.7 ng/L). The MBR effluents (RO influent) for May, June, and July were 117.2, 116.9, and $116.4 \mathrm{ng} / \mathrm{L}$, respectively. Testosterone concentrations showed greater variation between the different samples with the highest as mentioned before with a raw influent concentration of $281.3 \mathrm{ng} / \mathrm{L}$ (Figure 2B) and lowest concentration after the MBR/RO process with an RO effluent (Figure 3C) of $11.4 \mathrm{ng} / \mathrm{L}$. Testosterone levels measured corresponded well with those measured by Stalter et al. (2011) [35] in Switzerland and Germany (21 to $400 \mathrm{ng} / \mathrm{L}$ ) and Manickum et al. (2014) [36] in South Africa (11 to $343 \mathrm{ng} / \mathrm{L}$ ), whereas Fernandez et al. (2007) [37] in Canada and Chang et al.(2011) [38] in China, observed much lower concentrations ( 21 to $76.7 \mathrm{ng} / \mathrm{L}$ ). However, the disparity in concentrations 
measured by Leusch et al. (2006) [39] was much more extreme (113 to $4300 \mathrm{ng} / \mathrm{L}$ ). The mean MBR effluent before UF/NF/RO treatment was quite high, with an average value of 118ng/L (Figure 3C). Testosterone was almost completely removed in all the effluent samples after treatment with UF, NF, and RO membranes, with approximately $12 \mathrm{ng} / \mathrm{L}$ remaining (Figure 3C). This represents a removal efficiency of more than $90 \%$ as shown in Figure 2D, which is the same as recorded by Chang et al. (2011) [38] in China. The mean $E_{2}$ concentration (Figure 2C) for the UF, NF, and RO effluents were $2.22,0.66$, and $0.16 \mathrm{ng} / \mathrm{L}$, respectively. Figure 2D showed that the T concentration for the effluents of MBR, UF, NF, and RO in sequence with MBR process had lower T concentrations of 116.9, 12.75, 11.78 , and 11.66ng/L, respectively. UF, NF, and RO effluents had significantly reduced T concentrations compared with the influent at $134.9 \mathrm{ng} / \mathrm{L}\left(p=3.13 \times 10^{-20}\right.$ for UF, $p=4.67 \times 10^{-18}$ for NF, $p=4.51 \times$ $10^{-18}$ for $\left.\mathrm{RO} ; \alpha=0.05\right)$. The results were consistent with the previous study, indicating the downstream levels of the dams in Namibia with $\mathrm{E}_{2}$ and $\mathrm{T}$ concentrations of 7.2 and $19 \mathrm{ng} / \mathrm{L}$, respectively [27]. The three processes, $\mathrm{MBR} / \mathrm{UF}, \mathrm{MBR} / \mathrm{NF}$, and $\mathrm{MBR} / \mathrm{RO}$, exhibited relatively similar T removal percentage (Figure 3C). In the UF/NF/RO stages following the MBR treatment, the removal percentage of all the $\mathrm{T}$ effluents were crowded into a very high but narrow range (e.g., 89\% for UA60, 90\% for both NF270 and XLE). According to Yangali-Quintanilla (2011) [40] the residual natural organic matter (NOM) increases the membrane removal potential by increasing the negative surface charge of the membrane, which therefore increases the electrostatic repulsion. It is also possible that these new conditions lead to contaminant rejection as a result of increased hydrophobic interactions with the membranes.

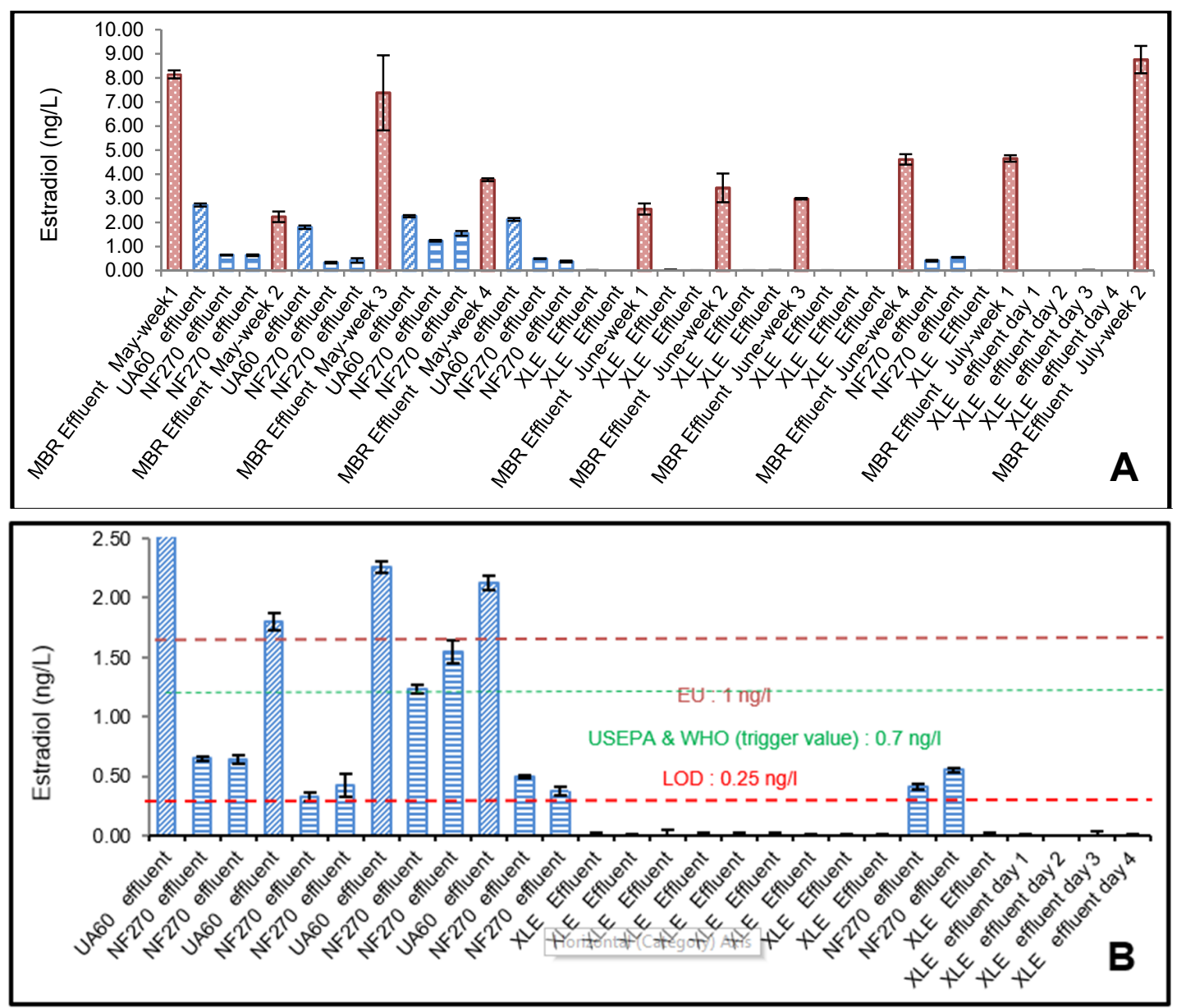

Figure 3. Cont. 


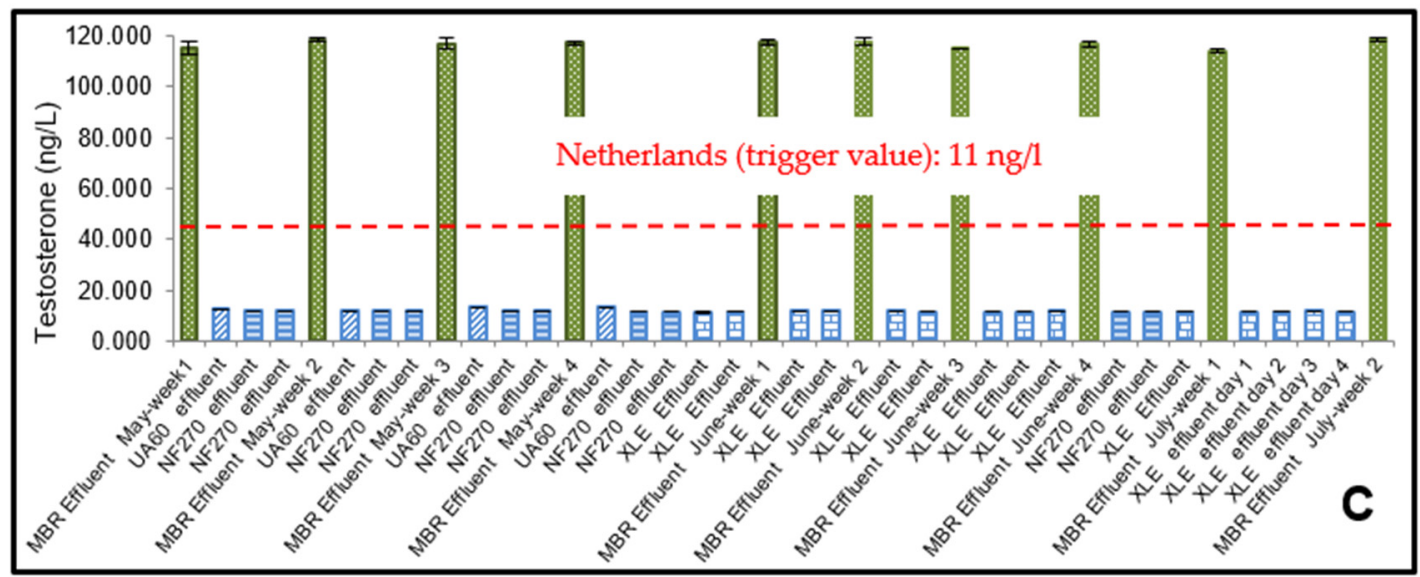

Figure 3. The mean ELISA of $17 \beta$-estradiol $\left(\mathrm{E}_{2}\right)(\mathrm{ng} / \mathrm{L})$ and testosterone $(\mathrm{T})$ levels $(\mathrm{ng} / \mathrm{L})$. (A) shows the ELISA mean of $17 \beta$-estradiol $\left(\mathrm{E}_{2}\right)$ levels $(\mathrm{ng} / \mathrm{L})$ measured in water collected from influent and effluents at various stages within the MWWW, including MBR and RO during winter (May, June, and July). Error bars denote SD; $n=2$. Error bars show maximum levels detected. (B) shows the ELISA mean of $17 \beta$-estradiol $\left(\mathrm{E}_{2}\right)$ levels (ng/L) measured of the effluents of the UF, NF, and RO membranes processes at various pilot plant conditions. Error bars denote SD; $n=2$. Error bars show maximum levels detected (EU, $1 \mathrm{ng} / \mathrm{L}$ modulate fish production [41]; US EPA and WHO, 0.70 trigger value for drinking water [42], level of detection (LOD): $0.25 \mathrm{ng} / \mathrm{L}$ ). (C) shows the ELISA mean of testosterone (T) levels (ng/L) measured in water collected from influent and effluents at various stages within the MWWW, including MBR and RO during winter (May, June, and July). Error bars denote SD; $n=2$. Error bars show maximum levels detected.

\subsection{The Effect of Flux on Testosterone}

The MBR/UF and MBR/NF systems were run at the same flux, but the MBR/RO system was run at two different fluxes (Table 1). An analysis of $\mathrm{T}$ removal rates by all systems implied that these filtration techniques can remove $\mathrm{T}$ to a very high extent (Figure 3C), although the results in all the applied fluxes were above the limit of quantification (LOQ) and on par with the Dutch drinking water trigger level of $11 \mathrm{ng} / \mathrm{L}$ [43]. Regardless of their high removal rates, however, T concentrations also exceeded the limit of detection (LOD). These results show that several molecules of $\mathrm{T}$ managed to penetrate the UF, NF, and RO membrane and, therefore, it was concluded that UF/NF/RO cannot serve as an absolute barrier to testosterone. Also, flux had no effect on testosterone removal. Sahar et al. (2011) [44] correspond with these findings in their investigation of the effect of three fluxes when removing MPs with CAS-UF/RO and MBR/RO systems.

\subsection{YES Analysis of $17 \beta$-Estradiol $\left(E_{2}\right)$}

During the recombinant yeast estrogenicity bioassay screening (YES) test, no estrogenic activity was measured in the extraction control samples; thus, contamination of the cartridges during the extraction process can be excluded. Yeast growth was checked at an absorbance of $620 \mathrm{~nm}$. Compared with the reference, none of the samples showed a decrease in cell density; therefore, no cytotoxicity was present. The sample was considered positive for estrogenic activity when three or more consecutive observations were above the level of detection (LOD) of the assay. The estrogenic activity (EEQs) of the samples was based on the $\mathrm{EC}_{50}$ value of the dose-response curves obtained for $17 \beta$-estradiol $\left(\mathrm{E}_{2}\right)$ and the test sample. The level of detection (LOD) was calculated for each bioassay and experiment using the mean activity of the negative control and adding threefold its standard deviation. As the LODs varied between bioassays and membrane experimental runs, they were not all shown for the sake of clarity. However, in general, only results above the LODs were considered. In a few cases, such as estrogenic activity, lower activities were shown because of their ecotoxicological relevance (low effect threshold) and for comparing membrane effectivities. 
Estrogenicity (binding to the human estrogen receptor (ER)) was detected in all feed samples analysed (Figure 2D). The raw influent had the highest proportion of estrogenic activity with $34.94 \mathrm{ng} / \mathrm{L}$ $\mathrm{E}_{2}$ equivalents (EEQs), followed by the average MBR influent (1.18 ng/L EEQs) and effluent (0.63 ng/L EEQs). The average MBR effluents (RO influent) for October, November, and December were 0.38, 0.74 , and $0.44 \mathrm{ng} / \mathrm{L}$ EEQs, respectively.

Although EEQs (Figure 4) followed a similar trend as $\mathrm{E}_{2}$ concentrations (Figure 3A,B), the YES EEQs were slightly lower than $\mathrm{E}_{2}$ concentrations measured using ELISA. This is consistent with the previous study indicating higher $\mathrm{E}_{2}$ ELISA concentrations [36]. The YES and ELISA assay screening methods were the same, generating similar results for $\mathrm{E}_{2}$ as shown before, and thus no YAS (yeast androgen screening) for $\mathrm{T}$ was performed because the results were expected to be similar.

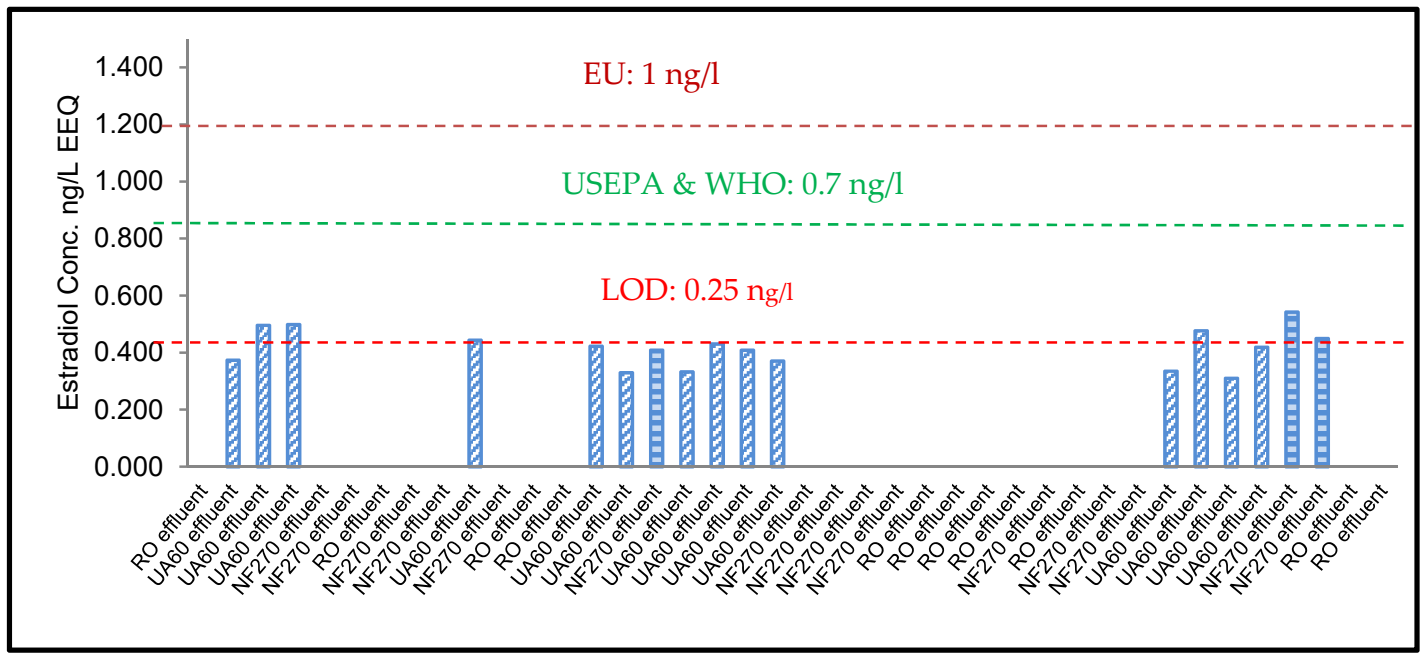

Figure 4. The YES of $17 \beta$-estradiol (E2) levels (ng/L estrogenic activity (EEQs)) measured in water collected from influent and effluents at various stages within the MWWW including MBR and RO, during October, November, and December (EU, $1 \mathrm{ng} / \mathrm{L}$ modulate fish production (Shappell et al., 2007); USEPA and WHO, 0.70 trigger value for drinking water [42], LOD: $0.25 \mathrm{ng} / \mathrm{L}$ ).

Variations in the pilot plant operating conditions in Table 1 (flux and $\mathrm{pH}$ ) did not have any visible effect on the removal of $\mathrm{E}_{2}$ and $\mathrm{T}$ for the MBR/UF, MBR/NF, and MBR/RO processes. Rasak et al. (2007) [45] commented that the $\mathrm{pH}$ and pressure had a noticeable influence on the rejection of organic compounds. Rasak et al. (2007) [45] used a lab-scale cell with synthetic feed, whereas our study used a pilot plant with a real-time MBR feed-in once-through mode.

The physico-chemical properties of $\mathrm{E}_{2}$ and $\mathrm{T}$ are considered as responsible for influencing their rejection by UF/NF/RO membranes [5,46]. This can be observed in Figure 3A,B, where the MBR/RO treatment removed all the test samples of $\mathrm{E}_{2}$ below $\mathrm{LOD}<0.25 \mathrm{ng} / \mathrm{L}$, regardless of the specific operating plant conditions. Most of the MBR/NF treatment test samples were below LOD $<0.25 n g / L$. The rest were visibly between 0.33 and $0.65 \mathrm{ng} / \mathrm{L}$. The MBR/UF treatment clearly showed poor removal of $\mathrm{E}_{2}$ with all four test samples between 2.12-2.72 ng/L. The retention of MPs in membrane separation processes depends on the characteristics of both the membrane and the pollutants. The hydrophobicity represented by the partitioning coefficient $\left(K_{\mathrm{ow}}\right)$ of $\mathrm{E}_{2}$ and $\mathrm{T}$ as well as the adsorption, size exclusion, and charge repulsion, would have major influences on the rejection. The molecular size would be the overriding factor in the rejection by the UF/NF/RO membranes [13].

Figure $5 \mathrm{C}$ shows that the EEQ values for the effluents of MBR, UF, NF, and RO in sequence with the MBR process had the very lowest estrogenic activities of $0.53,0.43$, and $0.088 \mathrm{ng}-\mathrm{EEQ} / \mathrm{L}$ and LOD, respectively. NF and $\mathrm{RO}$ effluents had significantly reduced estrogenic activity compared with the influent at $1.18 \mathrm{ng}-\mathrm{EEQ} / \mathrm{L}(p=0.187$ at for $\mathrm{UF}, p=0.005$ for $\mathrm{NF}, p=0.007$ for $\mathrm{RO} ; \alpha=0.05$ ). This is 
consistent with Ihara et al. (2014) [47],who showed highly reduced EEQ values in the effluent from advanced wastewater treatment processes with YES screening assays [32].
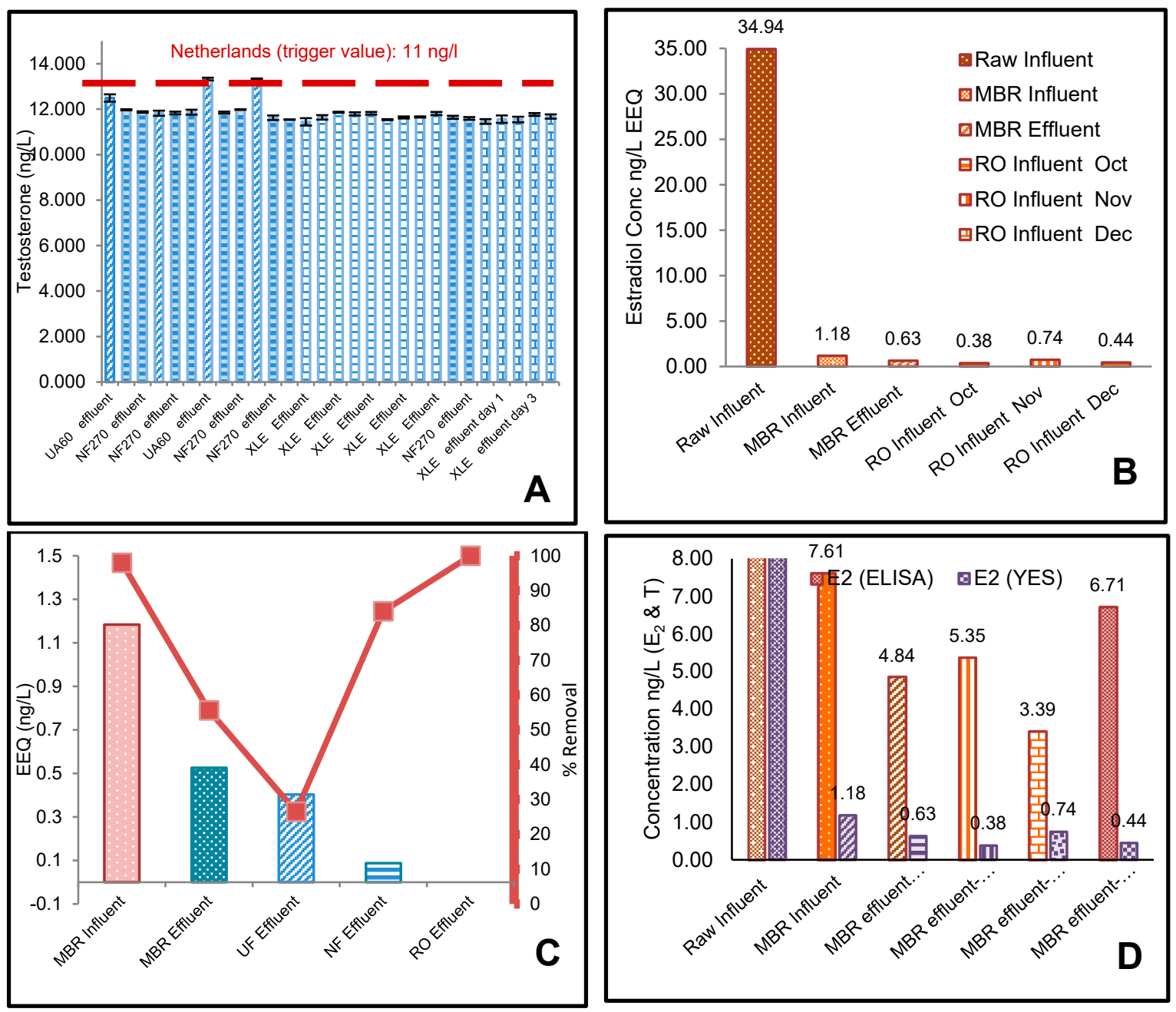

Figure 5. 17 $\beta$-Estradiol (E2) and testosterone (T) measured activity in collected samples from raw MWWTW and MBR influents as well as MBR effluents at six stages over three months, along with the percentage removal comparing the UF/NF/RO performance accordingly. (A) The ELISA mean of testosterone (T) levels (ng/L) measured of the effluents of the UF, NF, and RO membrane treatment at various pilot plant conditions. Error bars denote $\mathrm{SD} ; n=2$. Error bars show maximum levels detected (Netherlands, 11ng/L trigger value for drinking water from Brand et al. (2013) [43]. (B) shows the $\mathrm{E}_{2}$ YES analysis during October, November, and December. (C) $17 \beta$-Estradiol $\left(\mathrm{E}_{2}\right)$ levels (ng/L EEQs) measured in water collected from influents at five stages within the MWWTW including MBR and RO influent and effluent during summer (October, November, and December). (D) compares the ELISA and (YES) analysis results for $\mathrm{E}_{2}$.

A $91 \%$ removal of testosterone $(\mathrm{T})$ was recorded in the anaerobic (anoxic) tank, where the raw influent was reduced from almost 281.3 to $134.9 \mathrm{ng} / \mathrm{L}$ (Figure 2B,D). The lowest percentage removal (13\%) was measured by the MBR aerobic (oxic) tank, where the MBR influent was reduced from 134.9 to $116.9 \mathrm{ng} / \mathrm{L}$ only. UF, NF, and RO had expected percentage removals of $89 \%, 90 \%$, and $90 \%$, respectively.

Testosterone was poorly removed by all treatment processes, with all effluent test samples measuring an average of $12 \mathrm{ng} / \mathrm{L}$ (Figures $3 \mathrm{C}$ and $5 \mathrm{~A}$ ). This could be due to the high dipole moment of the $\mathrm{T}$ compound. It is reported that a high dipole moment of a compound would lead to a decrease in the rejection by membranes [48]. A 98\% removal of Estradiol was recorded in the anaerobic (anoxic) tank (Figure 5C), where the raw influent was reduced from almost 34.94 to $1.18 \mathrm{ng}-\mathrm{EEQ} / \mathrm{L}$ (Figure 5B). 
The lowest percentage removal (55\%) was measured by the MBR aerobic (oxic) tank, where the MBR influent was reduced from 1.18 to 0.53 ng-EEQ/L only. UF, NF, and RO had expected percentage removals of $27 \%, 84 \%$, and $100 \%$ (Figure 5 C).

\section{Results}

\subsection{Effect of Membrane Properties on the Rejection}

The removal of $\mathrm{E}_{2}$ and $\mathrm{T}$ was due to the direct filtration by the UF/NF/RO membranes (Figures 2D, 4 and $5 \mathrm{~A}-\mathrm{C}$ ). This was due to steric hindrance and their adsorption onto the polymeric membrane matrix. Adsorption can only contribute to short-term removal; as the feed is continuously filtered through the membrane, so membrane sites will be saturated with hydrophobic MPs. The charged and hydrophilic MPs did not adsorb to the polymeric membrane matrix and could be effectively removed by UF/NF/RO membranes via steric hindrance and electrostatic interaction mechanisms. Steric hindrance occurred because of the MW ( $\left.\mathrm{E}_{2}: 272.38 \mathrm{~g} / \mathrm{mol} ; \mathrm{T}: 288.42 \mathrm{~g} / \mathrm{mol}\right)$, which was larger than the membrane pore size (MWCO) of the RO ( $<200 \mathrm{Da})$ and NF $(400 \mathrm{Da})$. The rejection increased as the MW of the MPs increased. This explains the poor performance of the NF membrane. The UA60, NF270, and XLE membranes used for this study were negatively charged. Thus, electrostatic interactions occurred between the accused MPs ( $E_{2}$ and $\mathrm{T}$ ) and the negatively charged membrane surfaces, resulting in higher rejection compared to neutral solutes of a similar size. This result aligns with those of past studies $[13,23,24,26]$.

The thin-film composite RO and NF membranes have about the same thickness, but the active layer of the NF is weaker. The diffusion governs the rate of $E_{2}$ and $T$ transport across the membrane through the active skin layer. Freger et al. (2002) [49] explained that water is lightly soluble in the polymer where the diffusion process between $\mathrm{E}_{2}$ and $\mathrm{T}$ takes place in a polymeric matrix saturated with small amounts of water. The authors also mentioned that the convective flow has only a small contribution to the transport of $\mathrm{E}_{2}$ and $\mathrm{T}$ across the membrane, but the presence of water is thought to play an essential role in facilitating the diffusion process [24]. This can be observed in Figures 4 and 5C, where the NF/RO membrane treatment complemented MBR treatment very well, with the $\mathrm{E}_{2}$ and $\mathrm{T}$ being removed to below the level of detection $(0.25 \mathrm{ng} / \mathrm{L})$ with $84 \%$ and $100 \%$ removal, respectively.

The combination of MBR with UF/NF/RO led to enhanced removal of MPs. The MBR/RO achieved higher removal efficiencies of $E_{2}$ than MBR/NF and MBR/UF. Our observation is in good agreement with previous reports Nguyen et al. (2013) [23] and can be explained by the fact that NF270 and UA60 are loose membranes with a larger pore size and a higher permeability. This is also supported by the low conductivity rejection by the UA60 (10\%) and NF270 membrane (41-49\%) compared to the XLE membrane (93-95\%) [23]. The molecular weights of $E_{2}$ and $T$ were considerably smaller than the pore size of the UF (UA60) membrane; therefore, most of the MPs could not be physically retained by size exclusion, as shown in Figure 4, where the $\mathrm{E}_{2}$ ng/L EEQ was above the LOD $>0.25 \mathrm{ng} / \mathrm{L} \mathrm{EEQ}$, thus having only a $26.5 \%$ removal (Figure $5 \mathrm{C}$ ). Estradiol retention by the UF was due to adsorption to the membrane surface. This is clearly explained by Nghiem et al. (2004) [50] and Silva et al. (2012) [51], which consider the negative charge of the UF membrane and the dissociation constant of the MPs. McCallum et al. (2008) [52] investigated the adsorption and desorption processes occurring during the NF membrane filtration of $E_{2}$. They explained that the adsorption of $E_{2}$ onto the membrane and its desorption are dynamic processes, which meant that when the concentration of hormone in the feed solution is higher than in the membrane, adsorption will occur and the permeate concentration will increase until achieving an equilibrium; if the concentration in the feed solution is lower than the equilibrium concentration in the membrane, desorption will occur until a new equilibrium is reached.

Neale et al. (2009) [53] demonstrated that estradiol could interact with the bulk organic matter, including natural organic matter (NOM) surrogates such as humic acid. It adsorbs to the membranes through hydrophobic interaction, thus increasing the rejection. NF membranes retained estradiol due to both hydrophobic adsorption and size exclusion, whereas the UF membrane retained estradiol due 
to hydrophobic adsorption. This is well demonstrated in Figure 2D, where the NF (NF270) and UF (UA60) membranes achieved an $84 \%$ and $26.5 \%$ removal, respectively. This result aligns with those by authors Yoon et al. (2007) [54] and Silva et al. (2012) [51], where it can be concluded that estradiol retention by NF was significantly higher than that by UF. The removal rate of $E_{2}$ and $T$ using UF/NF/RO membranes is a function of the partitioning coefficient (log Kow) of $\mathrm{E}_{2}$ (4.01) and $\mathrm{T}$ (3.32), respectively. This was confirmed by Yoon et al. (2007) [54] who removed 25 MPs with UF and NF membranes, concluding that the retention increases with the increasing of the partitioning coefficient (log Kow). In the same research, a different retention trend was observed by Yoon et al. (2007) [54]—when MPs had a $\log$ Kow of $>2.8$, they exhibited a percentage removal less than $40 \%$, but when they had a $\log$ Kow $<2.8$, the percentage removal was more than $75 \%$. This could be the possible reason why $\mathrm{T}$ concentration was not removed below the measure $12 \mathrm{ng} / \mathrm{L}$ (89 removal percentage) throughout all treatment samples, as shown in Figure 5A,B.

\subsection{Risk Assessment of $17 \beta$-Estradiol $\left(E_{2}\right)$ and Testosterone (T)}

Despite the moderate-to efficient removal of estrogenicity by the MBR/UF, MBR/NF, and MBR/RO treatment, the measured EEQ values still pose a potential adverse health risk. As conventional risk assessment approaches are focussed on acute or chronic toxicity endpoints, the use of predicted no-effect concentrations (PNEC) and no-observed effect concentrations (NOEC) are mostly incorporated to assess potential lethal toxicity in aquatic wildlife [55]. However, such an approach is focussed mainly on the toxicity of individual chemicals and, therefore, does not consider the complex mixture of interactions of environmental pollutants within a water system. The YES offers a viable option that indicates the net estrogenic potential of a water sample to modulate hormone receptor binding, with the estimated EEQs providing a semi-quantitative assessment of all compounds, which may mimic an estrogenic response similar to $E_{2}$. It is, therefore, possible to compare such EEQ values to other toxicological studies [56].

The measured $\mathrm{E}_{2}$ and $\mathrm{T}$ concentrations were severely reduced in the effluent, although they were not removed completely during the UF treatment. This may still pose an environmental and health risk at very low nanograms per litre concentration levels. A multitude of studies has shown that the presence of natural steroid hormones in effluents has antagonistic effects on wildlife, including, among others, reduced fertility, abnormal development of male and female secondary sex characteristics, alteration in sex ratio, the feminisation of males, and change of behaviour [52]. Human and animal health is threatened when excess sewage effluent enters our water sources and effluent is used for irrigation application. In surface water, the effective lower LOQ for each was reduced to $0.97 \mathrm{ng} / \mathrm{L}$ for $\mathrm{E}_{2}$ and $4.15 \mathrm{ng} / \mathrm{L}$ for $\mathrm{T}[27,31]$. Results of the ELISA for the male steroid hormone T are presented in Figures $3 \mathrm{C}$ and $5 \mathrm{~A}$. All the effluent samples for the MBR/UF, MBR/NF, and MBR/RO were higher than the lower PNEC of the test, as well as the trigger value of $11 \mathrm{ng} / \mathrm{L}$ by Brand et al. (2013) [43]. Bandelj et al. (2006) [57] stated that androgenic substances in wastewater effluent could result in biological responses in animals, and the exposure of mosquitofish to androgenic substances in paper and pulp effluent has resulted in its masculinization [36].

The limit of detection (LOD) and limit of quantification (LOQ) were calculated as $3 \times$ standard deviation of the negative control and $6 \times$ standard deviation (SD) of the negative control, respectively [58]. The estrogenicity LOD was calculated as $0.25 \mathrm{ng} / \mathrm{L}$ (EEQ). Results of the ELISA and YES for the female steroid hormone $\mathrm{E}_{2}$ are presented in Figure $3 \mathrm{~A}, \mathrm{~B}$, Figure 4, respectively. All the $\mathrm{E}_{2}$ effluent samples with the MBR/UF, MBR/NF, and MBR/RO were lower than the lower LOQ of the test and were found to be less than the PNEC values for fish (1 $\mathrm{ng} \mathrm{E}_{2} / \mathrm{L}$ ) as proposed by Shappel et al. (2007) [41] and Faul et al. (2014) [27]. The PNECs are derived from the effect levels of the most sensitive test organism [59]. During in vivo vitellogenin (VTG) induction studies, the PNEC for $E_{2}$ is appropriate for the application in risk assessment of aquatic organisms. The PNEC value for long-term exposure (i.e., $>60$ days) in water is $2 \mathrm{ng} \mathrm{E}_{2} / \mathrm{L}$. Higher PNECs are recommended for short-term (i.e., a few days or weeks) exposure [60]. The authors summarise PNEC below $1 \mathrm{ng} / \mathrm{L}$ as having no risk and above $10 \mathrm{ng} / \mathrm{L}$ as being 
high risk [61]. This is also confirmed by Shappell et al. (2007) [41], who stated a PNEC of $1 \mathrm{ng} / \mathrm{L}$ from the England and Wales Environmental Agency (2002). Stephen et al. (1985) [62] suggested a PNEC of $0.75 \mathrm{ng} \mathrm{E}_{2} / \mathrm{L}$ EEQ for protecting aquatic organisms from chronic and full-lifecycle exposures to $\mathrm{E}_{2}$. Caldwell et al. (2012) [60] and his colleagues recommended a slightly higher PNEC for $\mathrm{E}_{2}\left(2 \mathrm{ng} \mathrm{E}_{2} / \mathrm{L}\right)$, which was derived from investigating 21 in vivo NOECs. The European Union recommended a PNEC of $(0.4 \mathrm{ng} / \mathrm{L}) \mathrm{E}_{2}$ for protecting aquatic life [63]. From the perspective of safeguarding aquatic species rather than fishes only, environmental researchers argue that $0.75 \mathrm{ng} \mathrm{E}_{2} / \mathrm{L}$ may be more reasonable than $2 \mathrm{ng} \mathrm{E}_{2} / \mathrm{L}$, and $0.75 \mathrm{ng} \mathrm{E}_{2} / \mathrm{L}$ may be more protective for aquatic organisms [63]. An estimated $\mathrm{E}_{2}$ trigger value of $0.7 \mathrm{ng} / \mathrm{L}$ [42] for drinking water standards and $0.4 \mathrm{ng} / \mathrm{L} \mathrm{EEQ} \mathrm{[64]} \mathrm{estrogenicity} \mathrm{for} \mathrm{long}$ term fish exposure has been proposed, on top of which further monitoring should be considered to establish the identity and origin of the MPs [30]. To estimate the exact source of estrogenicity within environmental samples may prove difficult, which was the reason why chemical analysis of known estrogenic micro-pollutants was not considered during this study, and this has been confirmed by a previous study [55].

\section{Conclusions}

In this investigation, it was shown that RO and NF membrane processes exhibited exceptional removal rates (>95\%) for $\mathrm{E}_{2}$ and $\mathrm{T}$. The influent $\mathrm{pH}$ and flux did not influence the rejection of $\mathrm{E}_{2}$ and $\mathrm{T}$, which was most likely ruled by adsorption, size exclusion, and diffusion simultaneously. Size exclusion was seemingly dominant, especially with NF and RO membranes. T, with a smaller partitioning coefficient (log Kow) value, was most likely adsorbed on the membranes and then passed through it to give a low rejection with all three membranes. It can be confirmed that the MBR/UF, MBR/NF, and MBR/RO comply with the USEPA, WHO, and EU trigger value PNEC as stipulated. It was found that RO showed higher removal percentages when compared with NF and UF. Consequently, domestic wastewater treated by MBR followed with NF or RO is adequate for the effective removal of natural steroid hormones.

Author Contributions: Conceptualization, M.A. and T.O.; data curation, M.A.; formal analysis, M.A. and T.O.; funding acquisition, T.O.; investigation, M.A.; methodology, M.A.; project administration, T.O.; resources, T.O.; software, M.A.; validation, M.A. and T.O.; visualization, M.A.; writing—original draft, M.A. All authors have read and agreed to the published version of the manuscript.

Funding: This research was funded by the National Research Foundation (NRF-RSA) and the Cape Peninsula University of Technology (CPUT).

Acknowledgments: The authors thank Kevin Sampson, Manager of Wastewater in the CoCT, for allowing us access to the MBR plant. We acknowledge the MWWTP manager and his personnel from WSSA (Water and Sanitation Services South Africa PTY LTD., JHB, RSA) for their assistance throughout our stay on-site. We thank Andre J Burger at the Department of Process Engineering Department at University of Stellenbosch for his guidance. Johannes van Wyk and his team at the Ecophysiology Laboratory, Department of Zoology (University of Stellenbosch) for their assistance with the ELISA and YES analysis, as well as Ian Goldie at Ikusasa Water PTY LTD., CT, RSA. Environmental Engineering Research Group (EnvERG) in the Chemical Engineering Department at Cape Peninsula University of Technology and the National Research Foundation (NRF-RSA).

Conflicts of Interest: The authors declare no conflict of interest.

\section{References}

1. Abbas, A.; Schneider, I.; Bollmann, A.; Funke, J.; Oehlmann, J.; Prasse, C.; Schulte-Oehlmann, U.; Seitz, W.; Ternes, T.; Weber, M.; et al. What you extract is what you see: Optimising the preparation of water and wastewater samples for in vitro bioassays. Water Res. 2019, 152, 47-60. [CrossRef] [PubMed]

2. Kase, R.; Javurkova, B.; Simon, E.; Swart, K.; Buchinger, S.; Könemann, S.; Escher, B.I.; Carere, M.; Dulio, V.; Ait-Aissa, S.; et al. Screening and risk management solutions for steroidal estrogens in surface and wastewater. TrAC Trends Anal. Chem. 2018, 102, 343-358. [CrossRef]

3. Vethaak, A.D.; Lahr, J.; Schrap, S.M.; Belfroid, A.C.; Rijs, G.B.J.; Gerritsen, A.; De Boer, J.; Bulder, A.S.; Grinwis, G.C.M.; Kuiper, R.V.; et al. An integrated assessment of estrogenic contamination and biological effects in the aquatic environment of The Netherlands. Chemosphere 2005, 59, 511-524. [CrossRef] [PubMed] 
4. Hu, X.; Shi, W.; Cao, F.; Hu, G.; Hao, Y.; Wei, S.; Wang, X.; Yu, H. Chemosphere Bioanalytical and instrumental analysis of estrogenic activities in drinking water sources from Yangtze River Delta. Chemosphere 2013, 90, 2123-2128. [CrossRef]

5. Silva, L.L.S.; Moreira, C.G.; Curzio, B.A.; da Fonseca, F.V. Micropollutant Removal from Water by Membrane and Advanced Oxidation Processes-A Review. J. Water Resour. Prot. 2017, 9, 411-431. [CrossRef]

6. Gillesby, B.E.; Zacharewski, T.R. Exoestrogens: Mechanisms of action and strategies for identification and assessment. Environ. Toxicol. Chem. 1998, 17, 3-14. [CrossRef]

7. Liu, Z.H.; Kanjo, Y.; Mizutani, S. Removal mechanisms for endocrine disrupting compounds (EDCs) in wastewater treatment-Physical means, biodegradation, and chemical advanced oxidation: A review. Sci. Total Environ. 2009, 407, 731-748. [CrossRef]

8. Elliott, B.; Muir, C.; deCatanzaro, D. Sources of variance within and among young men in concentrations of $17 \beta$-estradiol and testosterone in axillary perspiration. Physiol. Behav. 2017, 173, 23-29. [CrossRef]

9. Kim, S.D.; Cho, J.; Kim, I.S.; Vanderford, B.J.; Snyder, S.A. Occurrence and removal of pharmaceuticals and endocrine disruptors in South Korean surface, drinking, and waste waters. Water Res. 2007, 41, 1013-1021. [CrossRef]

10. Swart, N.; Pool, E. Rapid detection of selected steroid hormones from sewage effluents using an ELISA in the Kuils River water catchment area, South Africa. J. Immunoass. Immunochem. 2007, 28, 395-408. [CrossRef]

11. Myburgh, D.P.; Aziz, M.; Roman, F.; Jardim, J.; Chakawa, S. Removal of COD from Industrial Biodiesel Wastewater Using an Integrated Process: Electrochemical-Oxidation with $\mathrm{IrO}_{2}-\mathrm{Ta}_{2} \mathrm{O}_{5} / \mathrm{Ti}$ Anodes and Chitosan Powder as an Adsorbent. Environ. Process. 2019, 6. [CrossRef]

12. Kasongo, G.; Steenberg, C.; Morris, B.; Kapenda, G.; Jacobs, N.; Aziz, M. Surface grafting of polyvinyl alcohol (PVA) cross-linked with glutaraldehyde (GA) to improve resistance to fouling of aromatic polyamide thin film composite reverse osmosis membranes using municipal membrane bioreactor effluent. Water Pract. Technol. 2019, 14, 614-624. [CrossRef]

13. Bellona, C.; Drewes, J.E.; Oelker, G.; Luna, J.; Filteau, G.; Amy, G. Comparing nanofiltration and reverse osmosis for drinking water augmentation. J. Am. Water Works Assoc. 2008, 100. [CrossRef]

14. Hacıfazlığlu, M.C.; Parlar, İ.; Pek, T.; Kabay, N. Evaluation of chemical cleaning to control fouling on nanofiltration and reverse osmosis membranes after desalination of MBR effluent. Desalination 2019, 466, 44-51. [CrossRef]

15. Silva, B.; Tuuguu, E.; Costa, F.; Rocha, V.; Lago, A.; Tavares, T. Permeable Biosorbent Barrier for Wastewater Remediation. Environ. Process. 2017, 4, 195-206. [CrossRef]

16. Sert, G.; Bunani, S.; Yörüko, E.; Kabay, N.; Egemen, Ö.; Yüksel, M. Performances of some NF and RO membranes for desalination of MBR treated wastewater. J. Water Process Eng. 2017, 16, 193-198. [CrossRef]

17. Qin, J.J.; Kekre, K.A.; Tao, G.; Oo, M.H.; Wai, M.N.; Lee, T.C.; Viswanath, B.; Seah, H. New option of MBR-RO process for production of NEWater from domestic sewage. J. Membr. Sci. 2006, 272, 70-77. [CrossRef]

18. Tay, M.F.; Liu, C.; Cornelissen, E.R.; Wu, B.; Chong, T.H. The feasibility of nanofiltration membrane bioreactor $(\mathrm{NF}-\mathrm{MBR})+$ reverse osmosis $(\mathrm{RO})$ process for water reclamation: Comparison with ultrafiltration membrane bioreactor (UF-MBR)+RO process. Water Res. 2018, 129, 180-189. [CrossRef]

19. Racz, L.; Goel, R.K. Fate and removal of estrogens in municipal wastewater. J. Environ. Monit. 2010, 12, 58-70. [CrossRef]

20. Escher, B.I.; Aït-Aïssa, S.; Behnisch, P.A.; Brack, W.; Brion, F.; Brouwer, A.; Buchinger, S.; Crawford, S.E.; Du Pasquier, D.; Hamers, T.; et al. Effect-based trigger values for in vitro and in vivo bioassays performed on surface water extracts supporting the environmental quality standards (EQS) of the European Water Framework Directive. Sci. Total Environ. 2018, 628-629, 748-765. [CrossRef]

21. Aziz, M.; Kasongo, G. Scaling prevention of thin film composite polyamide Reverse Osmosis membranes by Zn ions. Desalination 2019, 464, 76-83. [CrossRef]

22. Agoro, M.A.; Okoh, O.O.; Adefisoye, M.A.; Okoh, A.I. Physicochemical Properties of Wastewater in Three Typical South African Sewage Works. Pol. J. Environ. Stud. 2018, 27, 491-499. [CrossRef]

23. Nguyen, L.N.; Hai, F.I.; Kang, J.; Price, W.E.; Nghiem, L.D. Removal of emerging trace organic contaminants by MBR-based hybrid treatment processes. Int. Biodeterior. Biodegrad. 2013, 85, 474-482. [CrossRef]

24. Nghiem, L.D.; Schäfer, A.I.; Elimelech, M. Removal of Natural Hormones by Nanofiltration Membranes: Measurement, Modeling and Mechanisms. Environ. Sci. Technol. 2004, 38, 1888-1896. [CrossRef] 
25. Nghiem, L.D.; Manis, A.; Soldenhoff, K.; Schäfer, A.I. Estrogenic hormone removal from wastewater using NF/RO membranes. J. Membr. Sci. 2004, 242, 37-45. [CrossRef]

26. Krzeminski, P.; Tomei, M.C.; Karaolia, P.; Langenhoff, A.; Almeida, C.M.R.; Felis, E.; Gritten, F.; Andersen, H.R.; Fernandes, T.; Manaia, C.M.; et al. Performance of secondary wastewater treatment methods for the removal of contaminants of emerging concern implicated in crop uptake and antibiotic resistance spread: A review. Sci. Total Environ. 2019, 648, 1052-1081. [CrossRef]

27. Faul, A.K.; Julies, E.; Pool, E.J. Steroid hormone concentrations and physiological toxicity of water from selected dams in Namibia. Afr. J. Aquat. Sci. 2014, 39, 189-198. [CrossRef]

28. Truter, J.C.; van Wyk, J.; Newman, B.K. In vitro screening for endocrine disruptive activity in selected South African harbours and river mouths. Afr. J. Mar. Sci. 2015, 37, 567-574. [CrossRef]

29. Sohoni, P.; Sumpter, J.P. Several environmental oestrogens are also anti-androgens. J. Endocrinol. 1998, 158, 327-339. [CrossRef]

30. Archer, E.; Petrie, B.; Kasprzyk-Hordern, B.; Wolfaardt, G.M. The fate of pharmaceuticals and personal care products (PPCPs), endocrine disrupting contaminants (EDCs), metabolites and illicit drugs in a WWTW and environmental waters. Chemosphere 2017, 174, 437-446. [CrossRef]

31. Faul, A.K.; Julies, E.; Pool, E.J. Oestrogen, testosterone, cytotoxin and cholinesterase inhibitor removal during reclamation of sewage to drinking water. Water SA 2013, 39, 499-506. [CrossRef]

32. Lee, J.; Lee, B.C.; Ra, J.S.; Cho, J.; Kim, I.S.; Chang, N.I.; Kim, H.K.; Kim, S.D. Comparison of the removal efficiency of endocrine disrupting compounds in pilot scale sewage treatment processes. Chemosphere 2008, 71, 1582-1592. [CrossRef]

33. Comerton, A.M.; Andrews, R.C.; Bagley, D.M.; Hao, C. The rejection of endocrine disrupting and pharmaceutically active compounds by NF and RO membranes as a function of compound and water matrix properties. J. Membr. Sci. 2008, 313, 323-335. [CrossRef]

34. Méndez, E.; González-Fuentes, M.A.; Rebollar-Perez, G.; Méndez-Albores, A.; Torres, E. Emerging pollutant treatments in wastewater: Cases of antibiotics and hormones. J. Environ. Sci. Health Part A Toxic/Hazard. Subst. Environ. Eng. 2017, 52, 235-253. [CrossRef]

35. Stalter, D.; Magdeburg, A.; Wagner, M.; Oehlmann, J. Ozonation and activated carbon treatment of sewage effluents: Removal of endocrine activity and cytotoxicity. Water Res. 2011, 45, 1015-1024. [CrossRef]

36. Manickum, T.; John, W. Occurrence, fate and environmental risk assessment of endocrine disrupting compounds at the wastewater treatment works in Pietermaritzburg (South Africa). Sci. Total Environ. 2014, 468-469, 584-597. [CrossRef]

37. Fernandez, M.P.; Ikonomou, M.G.; Buchanan, I. An assessment of estrogenic organic contaminants in Canadian wastewaters. Sci. Total Environ. 2007, 373, 250-269. [CrossRef]

38. Chang, H.; Wan, Y.; Wu, S.; Fan, Z.; Hu, J. Occurrence of androgens and progestogens in wastewater treatment plants and receiving river waters: Comparison to estrogens. Water Res. 2011, 45, 732-740. [CrossRef]

39. Leusch, F.D.L.; Chapman, H.F.; van den Heuvel, M.R.; Tan, B.L.L.; Gooneratne, S.R.; Tremblay, L.A. Bioassay-derived androgenic and estrogenic activity in municipal sewage in Australia and New Zealand. Ecotoxicol. Environ. Saf. 2006, 65, 403-411. [CrossRef]

40. Yangali-Quintanilla, V.; Maeng, S.K.; Fujioka, T.; Kennedy, M.; Li, Z.; Amy, G. Nanofiltration vs. reverse osmosis for the removal of emerging organic contaminants in water reuse. Desalin. Water Treat. 2011, 34, 50-56. [CrossRef]

41. Shappell, N.W.; Billey, L.O.; Forbes, D.; Matheny, T.A.; Poach, M.E.; Reddy, G.B.; Hunt, P.G. Estrogenic activity and steroid hormones in swine wastewater through a lagoon constructed-wetland system. Environ. Sci. Technol. 2007, 41, 444-450. [CrossRef]

42. Genthe, B.; Steyn, M.; Aneck-Hahn, N.; Van Zijl, C.; De Jager, C. The Feasibility of a Health Risk Assessment Framework to Derive Guidelines for Estrogen Activity in University of Pretoria; Water Research Commission: Pretoria, South Africa, 2010; ISBN 9781770059214.

43. Brand, W.; de Jongh, C.M.; van der Linden, S.C.; Mennes, W.; Puijker, L.M.; van Leeuwen, C.J.; van Wezel, A.P.; Schriks, M.; Heringa, M.B. Trigger values for investigation of hormonal activity in drinking water and its sources using CALUX bioassays. Environ. Int. 2013, 55, 109-118. [CrossRef]

44. Sahar, E.; David, I.; Gelman, Y.; Chikurel, H.; Aharoni, A.; Messalem, R.; Brenner, A. The use of RO to remove emerging micropollutants following CAS/UF or MBR treatment of municipal wastewater. Desalination 2011, 273, 142-147. [CrossRef] 
45. Rasak, A.R.A.; Ujang, Z.; Ozaki, H. Removal of endocrine disrupting chemicals (EDCs) using low pressure reverse osmosis membrane (LPROM). Water Sci. Technol. 2007, 56, 161-168. [CrossRef]

46. Ozaki, H.; Li, H. Rejection of organic compounds by ultra-low pressure reverse osmosis membrane. Water Res. 2002, 36, 123-130. [CrossRef]

47. Ihara, M.; Ihara, M.O.; Kumar, V.; Narumiya, M.; Hanamoto, S.; Nakada, N.; Yamashita, N.; Miyagawa, S.; Iguchi, T.; Tanaka, H. Co-occurrence of estrogenic and antiestrogenic activities in wastewater: Quantitative evaluation of balance by in vitro ER $\alpha$ reporter gene assay and chemical analysis. Environ. Sci. Technol. 2014, 48, 6366-6373. [CrossRef]

48. Van der Bruggen, B.; Braeken, L.; Vandecasteele, C. Evaluation of parameters describing flux decline in nanofiltration of aqueous solutions containing organic compounds. Desalination 2002, 147, 281-288. [CrossRef]

49. Freger, V.; Gilron, J.; Belfer, S. TFC polyamide membranes modified by grafting of hydrophilic polymers: An FT-IR/AFM/TEM study. J. Membr. Sci. 2002, 209, 283-292. [CrossRef]

50. Nghiem, L.D.; Schäfer, A.I. Trace contaminant removal with nanofiltration. Nanofiltr. Princ. Appl. 2004, 479-520.

51. Silva, C.P.; Otero, M.; Esteves, V. Processes for the elimination of estrogenic steroid hormones from water: A review. Environ. Pollut. 2012, 165, 38-58. [CrossRef]

52. McCallum, E.A.; Hyung, H.; Do, T.A.; Huang, C.H.; Kim, J.H. Adsorption, desorption, and steady-state removal of 17 $\beta$-estradiol by nanofiltration membranes. J. Membr. Sci. 2008, 319, 38-43. [CrossRef]

53. Neale, P.A.; Escher, B.I.; Schäfer, A.I. pH dependence of steroid hormone-organic matter interactions at environmental concentrations. Sci. Total Environ. 2009, 407, 1164-1173. [CrossRef] [PubMed]

54. Yoon, Y.; Westerhoff, P.; Snyder, S.A.; Wert, E.C.; Yoon, J. Removal of endocrine disrupting compounds and pharmaceuticals by nanofiltration and ultrafiltration membranes. Desalination 2007, 202, 16-23. [CrossRef]

55. Archer, E. Interaction of Pharmaceutical \& Personal Care Products (PPCPs) and Endocrine Disrupting Contaminants (EDCs) with Microbial Communities in South African Wastewater Treatment Works and Environmental Waters. Ph.D. Thesis, Stellenbosch University, Stellenbosch, South African, 2018; p. 224.

56. Archer, E.; Wolfaardt, G.M.; van Wyk, J.H. Pharmaceutical and personal care products (PPCPs) as endocrine disrupting contaminants (EDCs) in South African surface waters. Water SA 2017, 43, 684-706. [CrossRef]

57. Bandelj, E.; van den Heuvel, M.R.; Leusch, F.D.L.; Shannon, N.; Taylor, S.; McCarthy, L.H. Determination of the androgenic potency of whole effluents using mosquitofish and trout bioassays. Aquat. Toxicol. 2006, 80, 237-248. [CrossRef]

58. Cai, K.; Elliott, C.T.; Phillips, D.H.; Scippo, M.L.; Muller, M.; Connolly, L. Treatment of estrogens and androgens in dairy wastewater by a constructed wetland system. Water Res. 2012, 46, 2333-2343. [CrossRef]

59. Choi, K.; Kim, Y.; Park, J.; Park, C.K.; Kim, M.Y.; Kim, H.S.; Kim, P. Seasonal variations of several pharmaceutical residues in surface water and sewage treatment plants of Han River, Korea. Sci. Total Environ. 2008, 405, 120-128. [CrossRef]

60. Caldwell, D.J.; Mastrocco, F.; Anderson, P.D.; Länge, R.; Sumpter, J.P. Predicted-no-effect concentrations for the steroid estrogens estrone, $17 \beta$-estradiol, estriol, and $17 \alpha$-ethinylestradiol. Environ. Toxicol. Chem. 2012, 31, 1396-1406. [CrossRef]

61. Jiang, W.; Yan, Y.; Ma, M.; Wang, D.; Luo, Q.; Wang, Z.; Satyanarayanan, S.K. Assessment of source water contamination by estrogenic disrupting compounds in China. J. Environ. Sci. 2012, 24, 320-328. [CrossRef]

62. Stephan, C.E.; Mount, D.I.; Hansen, D.J.; Gentile, J.H.; Chapman, G.A.; Brungs, W.A. Guidelines for deriving numerical national water quality criteria for the protection of aquatic organisms and their uses. PB85-227049. Environ. Prot. 1985, 105.

63. Wu, B.; Kitade, T.; Haur, T.; Uemura, T.; Fane, A.G. Impact of membrane bioreactor operating conditions on fouling behavior of reverse osmosis membranes in MBR-RO processes. DES 2013, 311, 37-45. [CrossRef]

64. Jarošová, B.; Bláha, L.; Giesy, J.P.; Hilscherová, K. What level of estrogenic activity determined by in vitro assays in municipal waste waters can be considered as safe? Environ. Int. 2014, 64, 98-109. [CrossRef] [PubMed]

(C) 2020 by the authors. Licensee MDPI, Basel, Switzerland. This article is an open access article distributed under the terms and conditions of the Creative Commons Attribution (CC BY) license (http://creativecommons.org/licenses/by/4.0/). 